\section{2 Journal BiNET}

Vol. 04, Issue 02: 74-79

Journal of Bioscience and Agriculture Research

Home page: www.journalbinet.com/jbar-journal.html

\title{
Growth performance of Calamus tenuis Roxb. (Jali bet) in the coastal homesteads of Bangladesh
}

\author{
Sk. Ahiul Islam, Md. Abdul Quddus Miah, Md. Ahsan Habib and Md. Golam Rasul
}

Plantation Trial Unit Division, Bangladesh Forest Research Institute (BFRI), Rupatoli, Barisal-8206, Bangladesh

\begin{abstract}
Trials were conducted in the rural homesteads to assess the propagation and growth performance of Calamus tenuis (jali bet) planted in the year 2010 and 2011 at 5 different sites, namely Char Kukri-Mukri (Bhola), Rangabali (Patuakhali), Char Osman (Noakhali), Sitakundu (Chittagong) and Kolatoli (Cox's Bazar) in the coastal belt of Bangladesh. Data on survival, stem height, diameter, shoot production etc. were recorded from 4.5 years old and 3.5 years old two trial plantations. Result showed that the significantly greater stem height was recorded of $13.03 \mathrm{~m}$ at Rangabali, greater diameter was $1.53 \mathrm{~cm}$ at Cox's Bazar and the greater number of shoots per clump was 27.45 at Char Kukri-Mukri site at the age of 4.5 years raised in 2010. In another experiment raised in 2011, the significantly greater height was $14.44 \mathrm{~m}$ and the greater number of shoots produced per clump was 19.40 recorded from Rangabali site at the age of 3.5 years. The luxuriant stem growth was recorded from Char Kukri-Mukri and Rangabali areas and it was grown up to $21.15 \mathrm{~m}$ and $20.0 \mathrm{~m}$ respectively at the age of 4.5 years after planting. Therefore, this species can be planted in the coastal homesteads at wider scale for sustainable production of rattan (i.e., species of flexible palms in the tribe Calameae; an important non-timber mainly used for making baskets and furniture) resources in Bangladesh.
\end{abstract}

Key words: Growth, Calamus tenuis, homesteads, rattan, coastal belt and shoot production

Please cite this article as: Islam, S. A., Miah, M. A. Q., Habib, M. A. and Rasul, M. G. (2015). Growth performance of Calamus tenuis Roxb. (Jali bet) in the coastal Homesteads of Bangladesh. Journal of Bioscience and Agriculture Research 04(02): 74-79.

This article is distributed under terms of a Creative Common Attribution 4.0 International License

\section{Introduction}

Rattan is one of the most important renewable non-wood forest products that grow in the tropical regions of Africa and Asia. There are over 550 different species of rattan belonging to 12 genera distributed throughout the old world tropics (Dransfield et al., 2008). In Bangladesh, a total of 15 species of rattans were recorded (Alam, 1990; Basu, 1991; Ali, 2003) but recent investigation showed only 10 species of rattans under two genera growing in the country (Ara, 2005). All recorded rattan species, are forest-dwelling except Calamus tenuis (locally known as jali bet) and C. guruba (locally known as sundi bet) that have been domesticated from time immemorial. Generally, in the forests of Bangladesh, rattans are found in the northeastern hill forests of Chittagong, Cox's Bazar, Chittagong Hill Tracts and Sylhet. The climatic condition of Bangladesh is very suitable for rattan growing and it 
grows well in some cases without any special attention in its propagation, harvesting, extraction, processing and manufacture.

C. tenuis Roxb. is a climbing palm belonging to the family Arecaceae (Palmeae). It is a slender, stem cluster-forming, non deciduous, perennial plant up to $25 \mathrm{~m}$ long and $2.5 \mathrm{~cm}$ diameter (Peters and Henderson, 2014). The species occurs in plain to foothill slopes, river banks, wet, damp and shady areas (Alam, 1990). Ara (2008) reported that the species is usually found to grow at the edge of water and marshy places in village groves of Bangladesh. Due to its flexibility, durability and lightness, it is considered as unique multifunctional raw materials for handicraft and cottage industries. The culms of this rattan species are used for making furniture, baskets, handicrafts, binding material, decorative pieces, novelty items etc. The pulp of fruits is edible. Tender shoots are used as vegetables and as indigenous medicine. The plant also serves as soil binder, hedge and wildlife habitat. So, rattan is without question, one of the most important and widely used non-timber forest products in the world (Peters and Henderson, 2014). This rattan species was found in abundance in natural forests and village groves in the past in Bangladesh (Ara, 2008). Because of commercial demand, the major pressure mounted on natural rattan population only as there is no sufficient commercial rattan plantation in government forest land or private holdings. Due to over-exploitation and intensive logging of rattan and opening of natural forests, the natural population is also reducing drastically. The demand of raw materials is increasing day by day and the existing stock of resource is not enough to meet the present requirement. To fulfill the present demand of rattan resources and to increase the production of rattan, initiatives should be taken by government and non-government agencies. Steps for large scale plantation of rattan are not enough both in forest areas and village holdings. So, appropriate scientific knowledge on nursery development and silvicultural technique for plantation raising is needed for sustainable management of rattan resources.

Bangladesh coastline is $710 \mathrm{~km}$ long along the Bay of Bengal having numerous accreted lands and offshore islands (Siddiqi, 2001). There are 6.85 million homesteads in the coastal areas (Ahmad, 2004). Homesteads are a ready and sustainable source of food, fruit, vegetable, timber, fuel wood, fodder, building material, including bamboo and rattan, and also a source of cash income (Uddin et al., 2002). Homesteads represent a land use system involving deliberate management of multipurpose trees and shrubs in limited association with seasonal vegetables (Fernandes and Nair, 1986). Though the homesteads of Bangladesh are very productive but in the remote coastal areas, the homesteads are either barren or little vegetation. Farmers are not aware to cultivate their home garden with forest and rattan species although the use of rattans is well known in the rural areas (Nath et al., 2000). Various authors studied mostly propagation and nursery technique of rattan in Bangladesh in the plain and hilly lands (Mohiuddin et al., 1986; Mohiuddin and Ara, 1995; Siddiqi et al., 1996; Haider et al., 2014). No study has been undertaken aimed at propagation and growth performance of $C$. tenuis in the coastal homesteads of Bangladesh. Therefore, the study was conducted to assess the growth performance and productivity of $C$. tenuis in the homesteads of the remote coastal areas of Bangladesh.

\section{Materials and Methods}

The Plantation trial Unit Division of Bangladesh Forest Research Institute carried out experiments with C. tenuis at 5 locations in all along the coastal belt since 2010. Experiments were laid out at Char Kukri-Mukri under Bhola, Rangabali under Patuakhali, Char Osman under Noakhali, Sitakundu under Chittagong and Kolatoli under Cox's Bazar coastal district. These coastal districts lie between latitude $21^{0} 26^{\prime}-22^{0} 39^{\prime} \mathrm{N}$ and longitude $90^{0} 39^{\prime}-91^{0} 58^{\prime} \mathrm{E}$. The area forms the lowest landmass and is part of the delta of the extended Himalayan drainage ecosystem. The landscapes have been formed by the combined actions of rivers Meghna, Brahmaputra and Ganges. Soils in the delta consist primarily of sands, silts, silty sands, sandy silts and clayey silts (Anon, 1987). The delta soils occur in the coastal region of the Ganges tidal flood plain, the young Meghna estuarine flood plain and the old Meghna estuarine flood plain. Salinity of the soil and water at this region decreases toward north and increases towards east and west taking Bhola district in the centre. In monsoon, water salinity ranges from 3-27 parts per thousands (ppt) while in the dry season from 10-33 ppt (Siddiqi and Khan, 1990). Soil salinity ranges from $0.3-37.8 \mathrm{dS} / \mathrm{m}$ at different study sites. Temperatures range between 18 and $32^{\circ} \mathrm{C}$. 
The amount of rainfall varies from $3000 \mathrm{~mm}$ in the west, $2300 \mathrm{~mm}$ in the centre, and as high as 4000 $\mathrm{mm}$ in the east coastal belt (Siddiqi, 2002).

The most common propagation method for rattan is by seed. In this experiment, seedlings were raised from seeds in the nursery. The matured fruits were collected from phenotypically superior rattan plants. Fruits were soaked in water for 48 hours immediately after collection and then rubbing in water to remove mucilaginous protective coat by using wire mesh. Seeds were then sown in seed bed which was prepared by adding cow dung. Watering was done regularly in the seed bed. After 20-30 days of seed sowing, germination was started. Transplanting of seedlings was done when the first seedling leaves were fully expanded. At this stage, seedlings were uprooted carefully from the seed bed and then transplanted to the polybags of size $25 \mathrm{~cm} \times 15 \mathrm{~cm}$ filled with mixed powdered loamy soils and cow dung at 3:1 ratio. Seedlings were then kept under shed for one week. After that seedlings were placed on normal nursery beds and maintenance was done for another 10-12 months. Seedlings of rattan were distributed to the selected farmers for planting on the farmer's home garden during 2010 and 2011. In each year, 40 farmers were selected in each study site and 5-10 seedlings were distributed and planted in each homesteads. Planting was done under trees to support rattan seedlings to grow and climb. Mostly the supporting trees were mehgoni and rain tree. Data on seedlings survival, height, stem diameter at breast height, number of stems etc. were collected from the planted rattan groves in February 2015. Data were computed and analyzed using Microsoft office program Excel 2007 and Minitab statistical package developed at the Pennsylvania State University, USA during 1972.

\section{Results and Discussion}

Growth performance of $C$. tenuis planted in the year 2010 (4.5 years old) and 2011 (3.5 years old) at different sites of the coastal belt are shown in table 01 and 02. Plantation raised in 2010, the mean higher survival was found $42 \%$ at Char Kukri-Mukri and the lowest was only $27 \%$ at Cox's Bazar site. The significantly greater stem height was recorded $13.03 \mathrm{~m}$ at Rangabali and the lowest was $3.20 \mathrm{~m}$ at Cox's Bazar site. The maximum stem length was recorded $21.15 \mathrm{~m}$ at Char Kukri-Mukri, followed by $20.0 \mathrm{~m}$ at Rangabali island. Although the greater stem diameter was recorded $1.53 \mathrm{~cm}$ recorded at Cox's Bazar but no significant variation in diameter growth was found among different sites. The significantly greater number of shoots per clump was 27.45 at Char Kukri-Mukri and lowest was 7.29 at Cox's Bazar site. The average growth performance of this species at 4 sites was calculated. The average survival was $36.75 \%$, height was $8.0 \mathrm{~m}$, diameter was $1.40 \mathrm{~cm}$ and number of shoots production per clump was 17.44 at the age of 4.5 years after planting (Table 01 ).

Table 01. Growth performance of Calamus tenuis planted in 2010 (4.5 years old) at different location of the coastal belt of Bangladesh

\begin{tabular}{|l|c|c|c|c|c|c|c|}
\hline \multicolumn{1}{|c|}{ Location } & $\begin{array}{c}\text { Survival } \\
\%\end{array}$ & $\begin{array}{c}\text { Height of } \\
\text { main } \\
\text { shoot (m) }\end{array}$ & $\begin{array}{c}\text { Maximum } \\
\text { height (m) }\end{array}$ & $\begin{array}{c}\text { Diameter } \\
\text { of main } \\
\text { shoot } \\
\text { (cm) }\end{array}$ & $\begin{array}{c}\text { Maximum } \\
\text { diameter } \\
(\mathrm{cm})\end{array}$ & $\begin{array}{c}\text { No. of } \\
\text { shoot/ } \\
\text { clump }\end{array}$ & $\begin{array}{c}\text { Clump } \\
\text { girth (m) }\end{array}$ \\
\hline Rangabali & $38 \mathrm{a}$ & $13.03 \mathrm{a}$ & 20.0 & $1.43 \mathrm{a}$ & 2.98 & $24.70 \mathrm{a}$ & 1.98 \\
\hline Char Kukri & $42 \mathrm{a}$ & $10.18 \mathrm{~b}$ & 21.15 & $1.39 \mathrm{a}$ & 2.86 & $27.45 \mathrm{a}$ & 2.21 \\
\hline Char Osman & $40 \mathrm{a}$ & $5.60 \mathrm{c}$ & 7.50 & $1.26 \mathrm{a}$ & 3.18 & $10.32 \mathrm{~b}$ & 1.86 \\
\hline Cox's Bazar & $27 \mathrm{~b}$ & $3.20 \mathrm{c}$ & 9.20 & $1.53 \mathrm{a}$ & 3.25 & $7.29 \mathrm{~b}$ & 1.96 \\
\hline Average & 36.75 & 8.00 & - & 1.40 & - & 17.44 & 2.00 \\
\hline
\end{tabular}

In a column means having similar letter (s) are statistically identical and those having dissimilar letter (s) differ significantly as per 0.05 level of probability

Plantation raised in 2011, the maximum survival was recorded of $43 \%$ at Rangabali and the lowest was $39 \%$ at Char Osman site. The significantly greater height was $14.44 \mathrm{~m}$ recorded from Rangabali site and the lowest was $4.15 \mathrm{~m}$ from Char Osman site. The maximum stem length was $20.0 \mathrm{~m}$ at Rangabali followed by $18.00 \mathrm{~m}$ at Char Kukri-Mukri, $9.50 \mathrm{~m}$ at Char Osman and $6.50 \mathrm{~m}$ at Sitakundu 
sites. The mean greater stem diameter $(1.66 \mathrm{~cm})$ was recorded from Rangabali site and lowest was $0.86 \mathrm{~cm}$ from Sitakundu site. The maximum stem diameter $(3.45 \mathrm{~cm})$ was recorded from Char KukriMukri site. The greater number of shoot per clump was found 19.40 at Rangabali but it was only 3.0 at Sitakundu site. The average survival for all sites was $40.50 \%$, height was $7.69 \mathrm{~m}$, diameter was $1.23 \mathrm{~cm}$ and number of shoots production per clump was 9.86 at the age of 3.5 years after planting (Table 02).

Table 02. Growth performance of Calamus tenuis planted in 2011 (3.5 years old) at different location of the coastal belt of Bangladesh

\begin{tabular}{|l|c|c|c|c|c|c|c|}
\hline \multicolumn{1}{|c|}{ Location } & $\begin{array}{c}\text { Survival } \\
\%\end{array}$ & $\begin{array}{c}\text { Height of } \\
\text { main } \\
\text { shoot (m) }\end{array}$ & $\begin{array}{c}\text { Maximum } \\
\text { height (m) }\end{array}$ & $\begin{array}{c}\text { Diameter } \\
\text { of main } \\
\text { shoot } \\
\text { (cm) }\end{array}$ & $\begin{array}{c}\text { Maximum } \\
\text { diameter } \\
(\mathrm{cm})\end{array}$ & $\begin{array}{c}\text { No. of } \\
\text { shoot/ } \\
\text { clump }\end{array}$ & $\begin{array}{c}\text { Clump } \\
\text { girth (m) }\end{array}$ \\
\hline Rangabali & $43 \mathrm{a}$ & $14.44 \mathrm{a}$ & 20.00 & $1.66 \mathrm{a}$ & 3.15 & $19.40 \mathrm{a}$ & 2.16 \\
\hline Char Kukri & $40 \mathrm{a}$ & $7.07 \mathrm{~b}$ & 18.00 & $1.33 \mathrm{a}$ & 3.45 & $9.73 \mathrm{~b}$ & 0.84 \\
\hline Char Osman & $39 \mathrm{a}$ & $5.11 \mathrm{c}$ & 9.50 & $1.08 \mathrm{a}$ & 2.95 & $7.32 \mathrm{~b}$ & 1.44 \\
\hline Sitakundu & $40 \mathrm{a}$ & $4.15 \mathrm{c}$ & 6.50 & $0.86 \mathrm{a}$ & 1.65 & $3.00 \mathrm{c}$ & 0.52 \\
\hline Average & 40.50 & 7.69 & - & 1.23 & - & 9.86 & 1.24 \\
\hline
\end{tabular}

In a column means having similar letter (s) are statistically identical and those having dissimilar letter (s) differ significantly as per 0.05 level of probability

Siddiqi et al. (1996) carried out an experiment of $C$. tenuis at the Bangladesh Forest Research Institute campus, Chittagong and found an average seedling survival of $95.6 \%$ six months after planting. Authors also reported that average height of $C$. tenuis was $1.10 \mathrm{~m}$ and shoot production was 3.34 at the age of 18 months. In another experiment, Siddiqi et al. (2000) reported the growth performance of $C$. tenuis at different location of Bangladesh. Authors stated that height growth of the species was $6.5 \mathrm{~m}$ at Sylhet, $7.7 \mathrm{~m}$ at Chittagong, $5.0 \mathrm{~m}$ at Dhaka and $7.9 \mathrm{~m}$ at Tangail district at the age of 8 years and the shoot production per clump was 33.0, 23.5, 19.0 and 18.4 at Sylhet, Chittagong, Dhaka and Tangail respectively. However, diameters at breast height of the plant in Sylhet, Chittagong, Dhaka and Tangail were 1.1, 1.7, 1.3 and $1.1 \mathrm{~cm}$ respectively. Gulati and Sharma (1983) reported that $C$. tenuis showed luxuriant growth, attained an average height of $8.0 \mathrm{~m}$ after 8 years of planting and were grown up to $25.0 \mathrm{~m}$ at the age of 10 years at the Dehradun Forest Research Institute campus, India.

Considering the survival, height, diameter and shoot production, results of the study showed promising growth performance of $C$. tenuis in Rangabali and Char Kukri-Mukri sites in both planting years of 2010 and 2011. However, there were found low seedling survival at all planting sites. Actually many factors were responsible for low seedling survival of $C$. tenuis in the coastal home gardens. These were flooding by high tidal inundation during the monsoon, lacking of seedling maintenance by family members, soil salinity, draught in the dry season and grazing by domestic animals like buffalos, cows and goats.

\section{Conclusion}

C. tenuis is an economically important rattan species in Bangladesh. But the increasing demand of this species have resulted in their over exploitation during the past years. This situation is likely to worsen in the coming years unless efforts are made to raise artificial plantations in large scale in both forest areas and homesteads. Although survival of this species is poor in the coastal homesteads but promising growth and shoots production was observed in almost all sites of the coastal areas. Therefore, for the development of rattan population, large scale plantations programs with this species can be initiated with special care in all along the coastal belt. Thus, this can be an important source of income generation for the rural coastal people of Bangladesh. However, investigation of this experiment needs to be continued for another few years to determine further growth performance and harvesting schedule. 


\section{Acknowledgements}

We are grateful to the field staffs of Rangabali, Char Kukri-Mukri, Char Osman and Sitakundu Forest Research Stations of Plantation Trial Unit Division, Bangladesh Forest Research Institute for their sincere assistance in execution of field research activities at different sites of the coastal belt of Bangladesh.

\section{References}

[1]. Ahmad, M. (2004). Living in the coast: people and livelihoods. Program Development Office for Integrated Coastal Zone Management Plan Project. Water Resources Planning Organization, Dhaka. pp. 29.

[2]. Alam, M. K. (1990). Rattans of Bangladesh. Bulletin 7, Taxonomy Series. Bangladesh Forest Research Institute, Chittagong, Bangladesh. pp. 35.

[3]. Ali, S. S. (2003). Forest and Forestry. In: S. Islam and S. Miah, (eds.). Banglapedia-Vol. 4 (pp. 248250). Asiatic Society of Bangladesh, Dhaka.

[4]. Anon (1987). Coastal Environmental Management Plan for Bangladesh. Volume Two: Final Report. United Nations, Economic and Social Commission for Asia and the Pacific, Bangkok, Thailand. pp. 148.

[5]. Ara, R. (2005). Occurrence of C. gracilis Rox. in Sylhet district of Bangladesh. Indian Forester, 131 (9): 1238-1240.

[6]. Ara, R. (2008). An Overview of Rattan Resources in Bangladesh. Document No. 2, Market Development of Bamboo and Rattan Products with Potential. CFC INBAR-01 Project, Bangladesh Forest Research Institute, Chittagong, Bangladesh. pp. 9.

[7]. Basu, S. K. (1991). Living rattan collection in the Forest Research Institute, Chittagong. RIC Bulletin, 10 (2): 5-6.

[8]. Dransfield, J., Asmussen, N., Uhl, C., Baker, W., Harley, M. and Lewis, C. (2008). Genera Palmarum: The Evolution and Classification of Palms. Kew Publishing, London. pp. 732.

[9]. Fernandes, E. C. M. and Nair, P. K. R. (1986). An evaluation of the structure and function of tropical homegardens. Agroforestry System, 21: 279-310.

[10]. Gulati, N. K. and Sharma, B. K. (1983). Propagation of Calamus tenuis Roxb. Indian Forester, 109 (8): 541-545.

[11]. Haider, M. R., Alam, M. S., Hossain, M. A. and Shukor, N. A. A. (2014). Impact of pre-sowing treatment on seed germination and seedlings growth attributes of Calamus longisetus Griff. at nursery and field condition. Journal of Food, Agriculture \& Environment, 12 (4\&4): 395-399.

[12]. Mohiuddin, M. and Ara, R. (1995). Effect of different sowing media on the seed germination of Calamus tenuis Roxb. (Jali-bet). Chittagong University Studies, Part II : Science, 19 (2): 303-305.

[13]. Mohiuddin, M., Rashid, M. H. and Rahman, M. A. (1986). Seed germination and optimal time of transfer of seedlings of Calamus sp. From seed bed to polythene bag. Bano Biggyan Patrika, 15 (1\&2): 21-24.

[14]. Nath, T. K., Uddin, M. B. and Ahmed, M. (2000). Role of bamboo based cottage industry in economic upliftment of rural poor: A case study from rural Bangladesh. The Malaysian Forester, 63 (3): 98-105.

[15]. Peters, C. M. and Henderson, A. (2014). Systematics, Ecology and Management of Rattans in Cambodia, Laos and Vietnam. WWF-Greater Mekong and the New York Botanical Garden, Agricultural Publishing House. pp. 222.

[16]. Siddiqi, N.A. (2001). Mangrove Forestry in Bangladesh. Institute of Forestry \& Environmental Science, University of Chittagong, Bangladesh. pp. 201.

[17]. Siddiqi, N. A., Ara, R. and Merry, S. R. (1996). Germination and seedling growth of jali bet (Calamus tenuis Roxb.). Bangladesh Journal of Forest Science, 25 (1): 15-20.

[18]. Siddiqi, N. A., Ara, R. and Merry, S. R. (2000). Growth and harvesting of common rattans in Bangladesh. Bangladesh Journal of Forest Science, 29 (2): 97-105.

[19]. Siddiqi, N. A. (2002). Development and sustainable management of coastal plantations in Bangladesh. Journal of Asiatic Society of Bangladesh (Science), 28 (2): 144-166. 
[20]. Siddiqi, N. A. and Khan, M. A. S. (1990). Growth performance of mangrove trees along the coastal belt of Bangladesh. Mangrove Ecosystems Occasional Papers. No. 8. UNDP/UNESCO REGIONAL MANGROVES PROJECT RAS/86/120, Thomson Press, New Delhi, India. pp. 5-14.

[21]. Uddin, M. S., Rahman, M. J., Mannan, M. A., Bagum, S. A., Rahman, A. F. M. F. and Uddin, M. R. (2002). Plant biodiversity in the homesteads of saline area of southeastern Bangladesh. Pakistan Journal of Biological Science, 5(6): 710-714. 